\title{
Retinoid-related molecules require caspase 9 for the effective release of Smac and the rapid induction of apoptosis
}

\author{
FJ Lopez-Hernandez ${ }^{1}$, MA Ortiz ${ }^{1}$, Y Bayon ${ }^{1}$ and FJ Piedrafita ${ }^{1 *}$ \\ 1 Sidney Kimmel Cancer Center, San Diego, California 92121, USA \\ * Corresponding author: Dr F Piedrafita, Sidney Kimmel Cancer Center, 10835 \\ Altman Row, San Diego, CA 92121, USA. Tel: 858410 4188; \\ Fax: (858) 450 3251; E-mail: jpiedrafita@ skcc.org
}

Received 15.2.03; revised 27.7.03; accepted 28.8.03; published online 24.10.03 Edited by $G$ Salvesen

\begin{abstract}
Certain retinoid-related molecules (RRMs) with agonist or antagonist activities have been described to induce apoptosis in a variety of cancer cell lines and show promise for the treatment of cancer. Similar to other chemotherapeutic drugs, these retinoid analogs have been suggested to induce apoptosis through the intrinsic pathway, which requires the release of cytochrome $c$ from the mitochondria for the effective activation of caspase 9 . Expression of a catalytically inactive form of caspase 9, which functions as a dominant negative mutant, inhibits the induction of DEVDase activity and nuclear fragmentation by selective RRMs. Whereas the RRMs could induce the release of cytochrome $c$ in the absence of caspase 9 activity, the later is necessary for the effective release of Smac/Diablo from the mitochondria. Furthermore, overexpression of $\mathrm{Bcl}-2$ or $\mathrm{Bcl}-\mathrm{X}_{\mathrm{L}}$ also inhibits RRM-induced apoptosis. We demonstrate that activation of caspase 2 by the agonist MX2870-1 requires caspase 9 activity and is inhibited by Bcl-2 overexpression. In contrast, the antagonist MX781 induces cleavage of procaspase 2 upstream of mitochondria and independently of caspase 9. Thus, two retinoid analogs with unique characteristics activate two distinct apical caspases (2 or 9) to initiate apoptosis. In addition to caspase-mediated cell death, sustained exposure to the RRMs can also lead to loss of cell viability in cells lacking caspase 9 activity or in cells stimulated in the presence of the caspase inhibitor Z-VADfmk. Moreover, MX2870-1 and MX781 produce cell cycle arrest independently of caspase activity and the retinoid receptors. Cell Death and Differentiation (2004) 11, 154-164. doi:10.1038/ sj.cdd. 4401329

Published online 24 October 2003
\end{abstract}

Keywords: retinoids; caspase 9; Smac; growth arrest

Abbreviations: AFC, 7-amino-trifluoromethyl coumarin; BrdU, 5-bromo-2'-deoxyuridine; C9DN, caspase 9 dominant negative; DEVD, Asp-Glu-Val-Asp; DISC, death-inducing signaling complex; DN, dominant negative; Fmk, fluoromethylketone; IAP, inhibitor of apoptosis protein; PBS, phosphate buffer saline; PI, propidium iodide; RAR, retinoic acid receptor; RRM, retinoidrelated molecule; Smac, second mitochondria-derived activator of caspase

\section{Introduction}

The initiation and execution of apoptosis fundamentally relies on the activation of a family of cystein proteases named caspases that cleave target cellular substrates in an aspartate-directed manner. ${ }^{1,2}$ Apoptotic caspases are grouped in two subfamilies: initiator caspases and effector or executioner caspases. There are two major pathways leading to the activation of caspases during apoptosis. Stress, radiation, most chemotherapeutic drugs, and DNA damage induce apoptosis through an intrinsic pathway, which involves the mitochondria as the operations center to which signals converge. ${ }^{3}$ Mitochondrial membrane potential is rapidly lost and there is a massive release of proapoptotic factors into the cytosol, including cytochrome $c$, apoptosis-inducing factor, second mitochondria-derived activator of caspase (Smac)/ Diablo, endonuclease $\mathrm{G}$, and the serine protease Omi/HtrA. ${ }^{4-}$ ${ }^{8}$ Released cytochrome $c$, along with Apaf-1 and procaspase 9 , forms the apoptosome ${ }^{9,10}$ causing the proteolytic autoactivation of caspase 9 , which in turn cleaves and activates effector caspases 3 and $7 .{ }^{11-14}$ Smac release is necessary for the effective activation of caspases through interactions with inhibitor of apoptosis proteins (IAPs). Recent evidence suggests that caspase 2 activation upstream of the mitochondria can provoke the release of mitochondrial proapoptotic factors and is essential for UV- and stress-induced apoptosis. ${ }^{15-17}$

A second mechanism of apoptosis initiation is triggered by extracellular signals that bind to cell surface death receptors, such as Fas/CD95, TNFR1, or DR-5, which activate the extrinsic pathway. Upon ligand binding, death receptors dimerize and engage in the formation of the deathinducing signaling complex (DISC), which contains at least the receptor, initiator procaspases 8 or 10 , and the protein adaptor Fas-associated death domain or TNFR1-associated death domain. ${ }^{18-20}$ This provokes the self proteolysis and activation of the initiator caspase, which then directly cleaves and activates effector caspases. ${ }^{21-23}$ The Bcl-2 family member Bid is cleaved by caspase 8 and targeted to the mitochondria, where it induces cytochrome $c$ release and unleashes the intrinsic apoptotic machinery, providing a direct link between both apoptotic pathways. ${ }^{24,25}$ In addition, caspase 8 can be activated independently of death receptor-mediated signals by certain anticancer drugs. ${ }^{26,27}$

Retinoids regulate important biological functions through the activation of the nuclear retinoid receptors, retinoic acid receptors (RARs) and retinoid $X$ receptors. Novel synthetic retinoid-related molecules (RRMs) that are selective agonists 
for RAR $\gamma$ (CD437, MX2870-1, and MX3350-1) as well as one RRM antagonist (MX781) have been found to exhibit strong antiproliferative and apoptotic-inducing activities against numerous cancer cell lines in vitro ${ }^{28-32}$ and in vivo ${ }^{33,34}$ Thus, they show promise as lead compounds for the treatment of cancer as single-drug therapy or in combination with other anticancer agents. ${ }^{35}$ These compounds are suspected to exert their apoptotic activity through a novel mechanism of retinoid action, which is independent of the nuclear receptors. ${ }^{32,36}$ CD437 has been suggested to induce apoptosis by directly targeting mitochondria, ${ }^{37}$ although nuclear export of the orphan receptor nur77 and relocation to the mitochondria has also been indicated to mediate CD437-induced apoptosis. ${ }^{38}$ We have previously shown that agonist RRMs induce a strong and sustained activation of stress kinases JNK and p38, which correlates with the induction of apoptosis. ${ }^{39} \mathrm{JNK}$ is necessary for the release of cytochrome $c$ during stressinduced apoptosis ${ }^{40}$ and is known to phosphorylate Bcl-2 and $\mathrm{Bcl}-\mathrm{X}_{\mathrm{L}}$, hindering their antiapoptotic function. ${ }^{41-43}$ This contrasts with other studies suggesting that $\mathrm{Bcl}-2$ phosphorylation is required for its antiapoptotic activity. ${ }^{4,45}$ Moreover, JNK-mediated phosphorylation of Bad, Bim, and Bmf enhances their apoptotic activity. ${ }^{46,47}$

Our previous studies suggested that RRMs could induce apoptosis through the intrinsic pathway. ${ }^{39,48}$ To gain more insight into the mechanism of RRM-induced apoptosis, we have analyzed the role of caspase 9 activity in Jurkat cells. We found that caspase 9 was necessary for the effective release of Smac, and the rapid induction of caspase-mediated apoptosis by both agonist and antagonist RRMs. Interestingly, the antagonist MX781 caused the cleavage of procaspase 2 independently of caspase 9 activity, while the agonist MX2870-1 required mitochondria and caspase 9 to effectively induce typical apoptotic phenotypes. Moreover, the RRMs could induce caspase-independent cell death in the absence of caspase 9 activity as well as cell cycle arrest in Jurkat cells overexpressing $\mathrm{Bcl}-2$.

\section{Results}

\section{Caspase 9 activity is essential for the rapid induction of apoptosis by selective RRMs}

To explore the requirement of caspase 9 activity in RRMinduced apoptosis in Jurkat cells, we expressed a mutant (C285A) of caspase 9 that lacks proteolytic activity. ${ }^{49-51}$ When overexpressed, this mutant functions as a dominant negative (DN) inhibiting caspase 9-mediated apoptosis in vivo, ${ }^{9}$ although it does not inhibit the activity of recombinant caspase 9 in vitro. $^{52}$ Stable transfected cells were selected with neomycin and several individual clones were isolated that expressed Flag-tagged C9DN (Figure 1a). This exhibited lower electrophoretic mobility and was overexpressed in excess as compared to endogenous wild-type caspase 9. Control cells were transfected with empty vector and selected for neomycin resistance as well. Surviving cells were used as a pool and exhibited identical behavior as parental nontransfected cells in response to RRMs or other apoptotic stimuli (data not shown).
The induction of apoptosis by the agonist MX2870-1 and the antagonist MX781 in different Jurkat cell clones expressing C9DN was examined. Both RRMs caused a substantial increase on DEVDase activity in a dose-dependent manner, which reached the maximum induction with $1 \mu \mathrm{M} \mathrm{MX} 2870-1$ and $4 \mu \mathrm{M} \mathrm{MX781}$ (see Ortiz et al. ${ }^{39}$ and data not shown). As observed in Figure 1b, Jurkat cells expressing C9DN mutant displayed reduced levels of DEVDase activity upon stimulation with a high dose of the RRMs. This correlated with diminished cleavage of PARP (Figure 1c). The autoproteolytic activation of caspase 9 was then assessed by immunodetection with an antibody that recognizes a p35 fragment originated by cleavage at residue Asp315. Expression of C9DN mutant greatly inhibited cleavage at Asp315, likely by competing with endogenous caspase 9 for apoptosome formation (Figure 1c). We selected clone number 1 for further studies and examined the effect of the RRMs on nuclear morphology. After $3 \mathrm{~h}$ of treatment with MX2870-1 or MX781, Jurkat-pcDNA cells exhibited nuclear changes typical of apoptosis, such as chromatin condensation and nuclear fragmentation, which were not observed in cells expressing C9DN (Figure 1d). C9DN expression also inhibited RRMmediated induction of DNA fragmentation and phosphatidylserine externalization (Figure 1e and data not shown) as well as the induction of DEVDase activity by other stimuli, including camptothecin, anisomycin, etoposide, and UV radiation (not shown).

The kinetics of caspase activation was subsequently examined in Jurkat-C9DN-1 cells and in control cells treated with MX2870-1 and MX781. The agonist MX2870-1 induced maximal DEVDase activity after only $3 \mathrm{~h}$ of treatment in Jurkat-pcDNA cells, whereas the antagonist MX781 induced higher levels of DEVDase activity that peaked after $6 \mathrm{~h}$ of stimulation (Figure 2a). The induction of DEVDase activity by either RRM was severely impaired in Jurkat-C9DN-1 cells and slightly increased after prolonged times of RRM stimulation. No DEVDase activity was detected in C9DN-expressing cells treated with lower concentrations of the RRMs (not shown). For comparison, cells were also stimulated with anti-Fas antibody. Although Fas signals induce apoptosis via the extrinsic pathway, ${ }^{53}$ inhibition of Fas-induced cell death by C9DN has been described in MCF-7 cells, ${ }^{50}$ although another study showed that C9DN mutant did not protect Jurkat cells from Fas-mediated apoptosis. ${ }^{54}$ We observed that the amount of DEVDase activity induced by anti-Fas was considerably lower in Jurkat-C9DN cells than in control cells. The discrepancy between our results and others ${ }^{54}$ could be due to differences in the expression levels of exogenous C9DN.

The reduced increase of DEVDase activity observed in mutant cells stimulated with MX2870-1 was independent of caspase 9 autocatalytic activation, since no p35 fragment was detected by immunoblot (Figure 2b). A very low increase of caspase 9 p35 fragment was seen in Fas- and MX781-treated cells only when the film was overexposed. This contrasted with the substantial amounts of p35 fragment detected in control cells treated with either stimulus. In addition, extensive degradation of PARP was observed after only $6 \mathrm{~h}$ of treatment in Jurkat-pcDNA cells. An evident delay was seen in Jurkat-C9DN cells, which was more remarkable in MX2870-1-treated cells. 
a

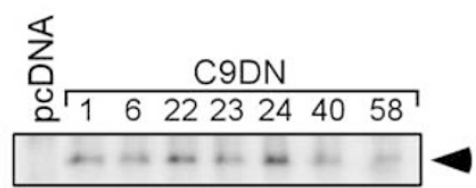

IB: Flag

C 1

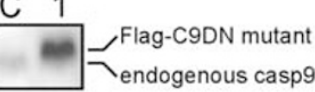

IB: casp-9 b

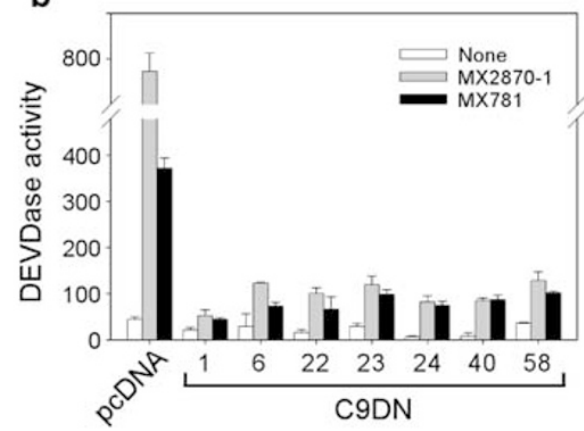

C
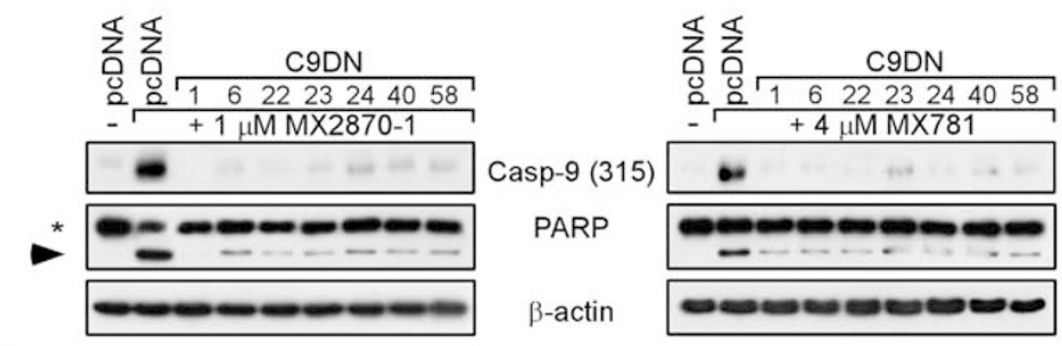

d

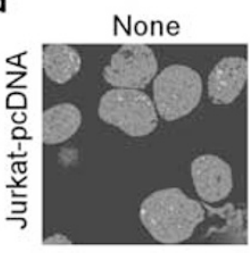

MX2870-1
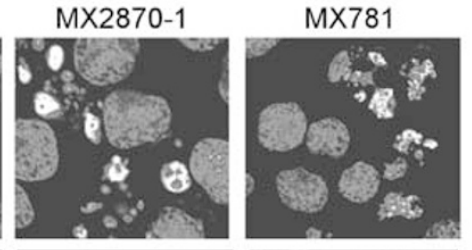

e
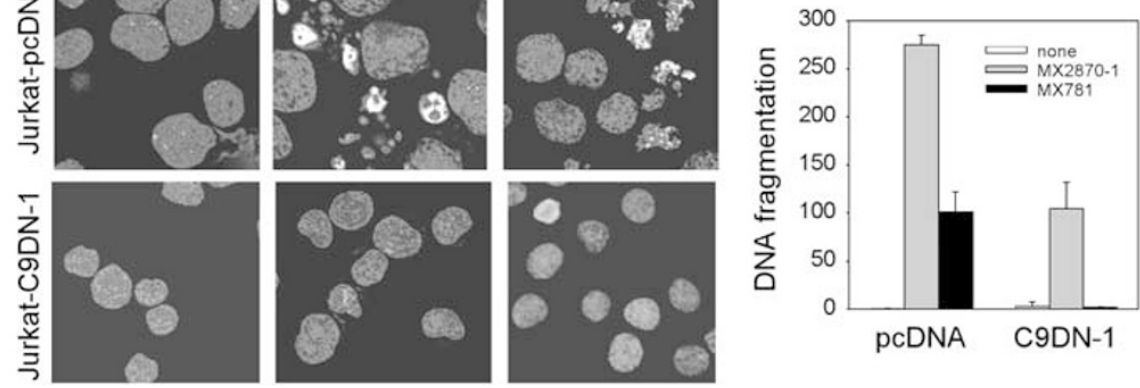

Figure 1 Stable overexpression of a catalytically inactive mutant of caspase 9 inhibits apoptosis in Jurkat cells. Characterization of Jurkat cells overexpressing C9DN. (a) Immunoblot analysis of whole-cell extracts obtained from Jurkat-pcDNA and several C9DN clones. In all, $25 \mu \mathrm{g}$ of protein extract in RIPA buffer were analyzed by SDS-PAGE followed by immunoblot with anti-Flag (M2) antibody. Below, immunoblot analysis with a polyclonal antibody that recognizes procaspase 9 shows the relative expression levels of the proenzyme in control (C) and Jurkat-C9DN-1 (1) cells. (b) Induction of DEVDase activity in C9DN clones by selective RRMs. Cells were treated with solvent (white columns), $1 \mu \mathrm{M}$ MX2870-1 (gray columns), or $4 \mu \mathrm{M}$ MX781 (black columns) for $3 \mathrm{~h}$, when cytosolic extracts were prepared in CE buffer and analyzed for DEVDase activity. The average activity (arbitrary units) \pm S.D. of two independent experiments performed in triplicate is shown. (c) Protein extracts obtained in RIPA buffer were analyzed for activation of caspase 9 and cleavage of PARP. Control cells and the indicated C9DN clones were treated as described in (b). Protein (25 $\mu \mathrm{g})$ extract was analyzed by SDS-PAGE and immunoblot with the indicated antibodies. Full-length PARP is shown with an asterisk. The arrowhead indicates one cleavage product. (d) Changes in nuclear morphology induced by RRMs. Control and C9DN-1 cells were treated with $1 \mu \mathrm{M}$ MX2870-1 or $4 \mu \mathrm{M}$ MX781 for $3 \mathrm{~h}$, when cells were stained with Hoescht and analyzed by fluorescence microscopy. (e) Induction of DNA fragmentation. Jurkat-pcDNA and C9DN-1 cells were treated as indicated before, and cytosol extracts were prepared and analyzed by ELISA to quantitate DNA fragmentation. The fold induction (average \pm S.D. of four independent experiments performed in duplicate) is shown

\section{Expression of $\mathrm{Bcl}-2$ and $\mathrm{Bcl}-\mathrm{X}_{\mathrm{L}}$ in Jurkat cells prevents RRM-induced apoptosis}

Overexpression of $\mathrm{Bcl}-2$ or $\mathrm{Bcl}-\mathrm{X}_{\mathrm{L}}$ prevents apoptosis induced by numerous stimuli, including the RRM agonist CD437..$^{37,55}$ To further investigate the role of mitochondria in the induction of apoptosis by MX2870-1 and MX781, we transfected Jurkat cells with $\mathrm{Bcl}-2$ or $\mathrm{Bcl}-\mathrm{X}_{\mathrm{L}}$ expression vectors and isolated several individual clones (Figure $3 a$ and data not shown). The induction of DEVDase activity, DNA fragmentation, and externalization of phosphatidylserine in response to RRM treatment was completely abolished in all clones overexpressing Bcl-2 or Bcl- $\mathrm{X}_{\mathrm{L}}$ (Figure 3b,c and data not shown). In agreement with previously reported data, ${ }^{56,57} \mathrm{Bcl}-2$ as well as
$\mathrm{Bcl}-\mathrm{X}_{\mathrm{L}}$ also inhibited the induction of apoptosis mediated by Fas signals (Figure 3b,c). The inhibition of DEVDase activity and DNA fragmentation by $\mathrm{Bcl}-2$ was observed even after $24 \mathrm{~h}$ of incubation with the RRMs (data not shown).

\section{Caspase 9 is necessary for the effective release of Smac/Diablo from the mitochondria}

We further examined the release of cytochrome $c$ and Smac from the mitochondria in Jurkat cells overexpressing C9DN and $\mathrm{Bcl}-2$. We observed no accumulation of cytochrome $c$ and Smac in the cytosol of Jurkat-Bcl-2 (Figure 4a) or Jurkat-Bcl- $\mathrm{X}_{\mathrm{L}}$ (not shown) cells treated with the RRMs. In contrast, inhibition 

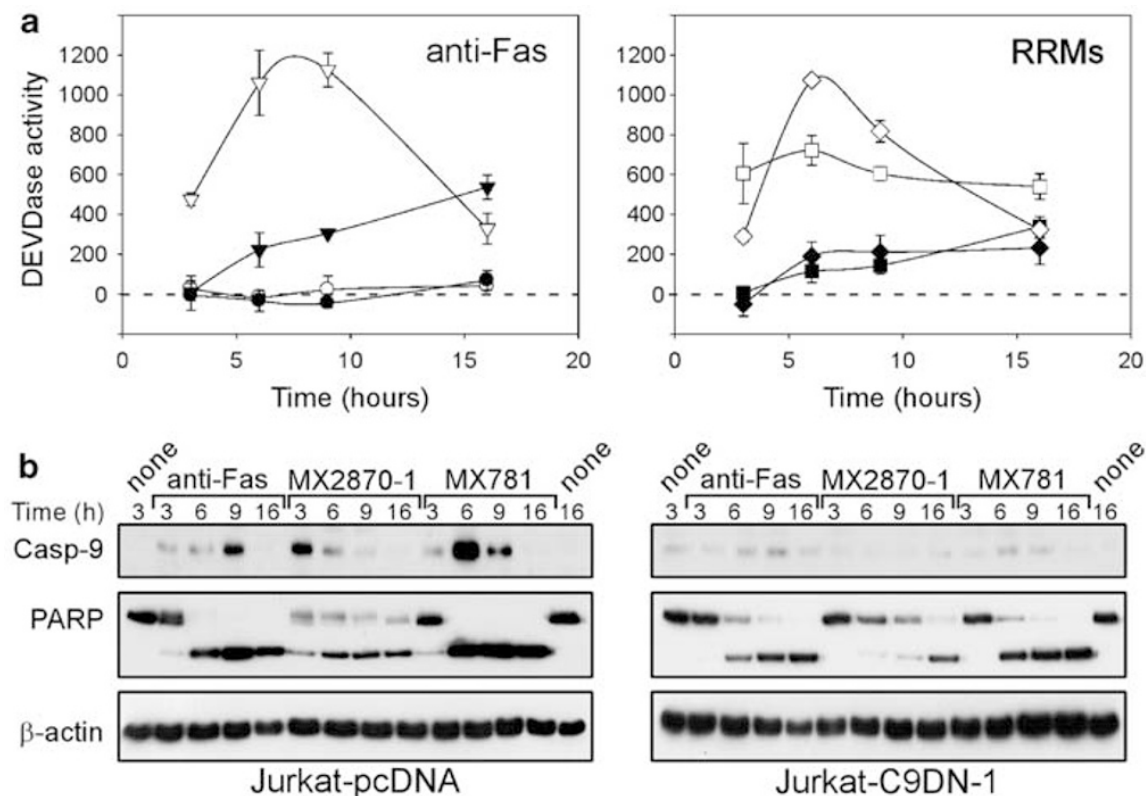

Figure 2 Kinetics of caspase activation. (a) Induction of DEVDase activity. Jurkat-pcDNA (open symbols) or Jurkat-C9DN-1 (closed symbols) cells were treated with solvent (circles), $167 \mathrm{ng} / \mathrm{ml}$ anti-Fas antibody (inverted triangles), $1 \mu \mathrm{M}$ MX2870-1 (squares), or $4 \mu \mathrm{M}$ MX781 (diamonds). At the indicated times, cells were harvested and lysed in RIPA buffer. DEVDase activity was determined as described in Materials and Methods using triplicate assays. The experiment was repeated twice and the average \pm S.D. is shown. (b) Immunoblot analysis of caspase 9 autoprocessing (p35 fragment) and cleavage of PARP was performed using the extracts prepared in (a). The caspase 9 blot of Jurkat-pcDNA (left) shown is a 1 min exposure, whereas the blot of Jurkat-C9DN-1 (right) was exposed for 30 min. Protein loading was normalized by immunodetection with an anti- $\beta$-actin antibody

of caspase 9 activity had no significant effect on cytochrome $c$ release, but substantially prevented the translocation of Smac/ Diablo induced by the RRMs and anti-Fas (Figure 4a). These findings support previous studies suggesting that caspase activity is necessary for the release of Smac. ${ }^{58}$ Protein loading was normalized with a nonspecific band of $\sim 70 \mathrm{kDa}$ that appeared with the anti-cytochrome $c$ antibody (Figure $4 a$ ) and with anti- $\beta$-actin antibody (not shown).

Although originally described as an inhibitor of cathepsins $B$ and $L$, we recently observed that Z-FA-fmk can efficiently inhibit effector caspases in vitro and in intact cells, while eliciting little or no effect on initiator caspases. ${ }^{48}$ We therefore explored the effect of Z-FA-fmk on Smac release. The inhibitor had no effect whatsoever on RRM-induced release of Smac (Figure 4b) at concentrations that inhibited DEVDase-like activity (see Lopez-Hernandez et al. ${ }^{48}$ ). In contrast, the pan-caspase inhibitor Z-VAD-fmk completely abrogated Smac release induced by $M \times 2870-1$ and anti-Fas, but partially repressed $M \times 781$-induced Smac translocation (Figure 4b). Together, these data demonstrate that caspase 9 activity and not effector caspases is necessary for the effective release of $\mathrm{Smac}$, although other activities induced by the antagonist MX781 upstream of caspase 9 could also produce a similar effect in the absence of caspase 9 activity.

\section{The antagonist MX781, but not the agonist MX2870-1, activates caspase 2 upstream of mitochondria}

To gain further insight into the mechanism of caspase activation by the different RRMs, we analyzed the proteolytic maturation of caspases by Western blot. Bcl-2 overexpression completely blocked the activation of caspases 8 and 9 induced by the selective RRMs and anti-Fas, and no significant levels of cleaved caspase 3 were detected (Figure 5a). On the other hand, C9DN overexpression prevented to a large extent the full processing of caspases 3 and 8 induced by the RRMs, but only partially inhibited Fasmediated signals.

Significant degradation of procaspase 2 was detected in Jurkat-pcDNA cells stimulated with both RRMs and anti-Fas. Bcl-2 and C9DN expression prevented the processing of procaspase 2 induced by anti-Fas and the agonist RRM MX2870-1, indicating that effector caspases were probably responsible for the activation of caspase $2 .{ }^{13}$ Interestingly, the antagonist MX781 induced caspase 2 cleavage in Bcl-2- and C9DN-expressing cells to levels comparable to those seen in Jurkat-pcDNA cells (Figure 5a), suggesting an apical role for caspase 2 in MX781-induced apoptosis. ${ }^{17}$ Slightly higher levels of procaspase 2 were observed in untreated Jurkat-Bcl2 cells, which were not due to differences in protein loading (see Figure 4a and data not shown).

Although the autoproteolytic cleavage of caspase 9 at Asp315 (fragment p35) induced by either signal was completely inhibited in Jurkat-C9DN cells, we detected a p37 fragment, which corresponds to cleavage at Asp330 by caspase 3-like activity (Figure 5a). The reasons for the observed increase in C9DN cells treated with anti-Fas are not fully understood. Using a polyclonal antibody that recognized full-length caspase 9 , we demonstrated that procaspase 9 was completely cleaved in Jurkat-C9DN cells stimulated with MX781 and Fas signals, but not in cells stimulated with the agonist RRM MX2870-1 (Figure 5b). Low levels of caspase 3 
a
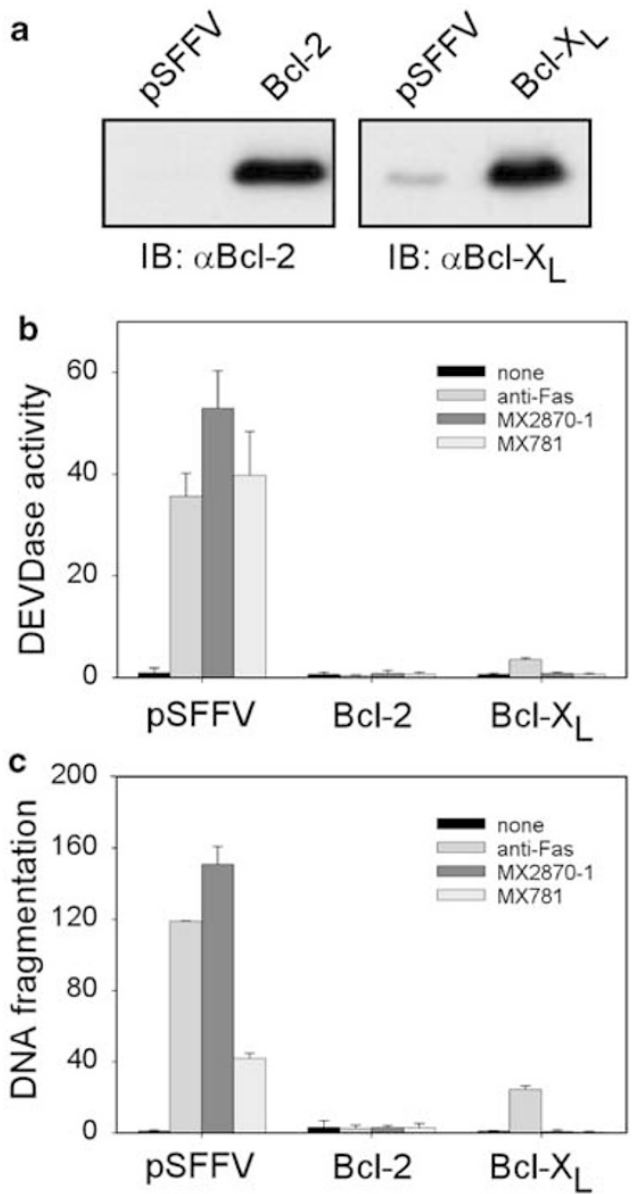

Figure 3 Stable overexpression of $\mathrm{Bcl}-2$ and $\mathrm{Bcl}-\mathrm{X}_{\mathrm{L}}$ inhibits apoptosis in Jurkat cells. (a) Overexpression of Bcl-2 (left) and Bcl- $X_{\mathrm{L}}$ (right) in stable transfected clones was analyzed by immunoblot with the corresponding antibodies. Jurkat cells stably transfected with $\mathrm{pSFFV}, \mathrm{Bcl}-2$ or $\mathrm{Bcl}-\mathrm{X}_{\mathrm{L}}$ were treated for $3 \mathrm{~h}$ with

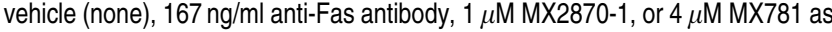
indicated. Cytosolic extracts were prepared in CE buffer and tested for DEVDase activity (b) and DNA fragmentation (c). Data represent the average (fold induction) \pm S.D. of two $\left(\mathrm{Bcl}-\mathrm{X}_{\mathrm{L}}\right)$ or three $(\mathrm{Bcl}-2)$ independent experiments performed in triplicate

activity were detected in Fas-stimulated Jurkat-C9DN cells, as demonstrated by immunoblot (Figure $5 \mathrm{a}$ ) or by enzymatic DEVDase assay (Figure1b and data not shown), which could be responsible for the cleavage of procaspase 9 present in large excess. In addition to caspase 3-like activity, caspase 8 could be directly or indirectly involved in caspase 9 degradation upon Fas stimulation. In cells treated with MX781, activation of caspase 2 upstream of mitochondria might be involved in the cleavage of caspase 9 . Alternatively, some of the proapoptotic factors released from the mitochondria by caspases 2 or 8 could also be implicated, since cleavage of caspase 9 was inhibited by overexpression of Bcl-2.

\section{Caspase 9 activity is required for the full maturation of apoptotic bodies}

We analyzed next the effect of selective RRMs on cellular morphology. The appearance of typical mature apoptotic

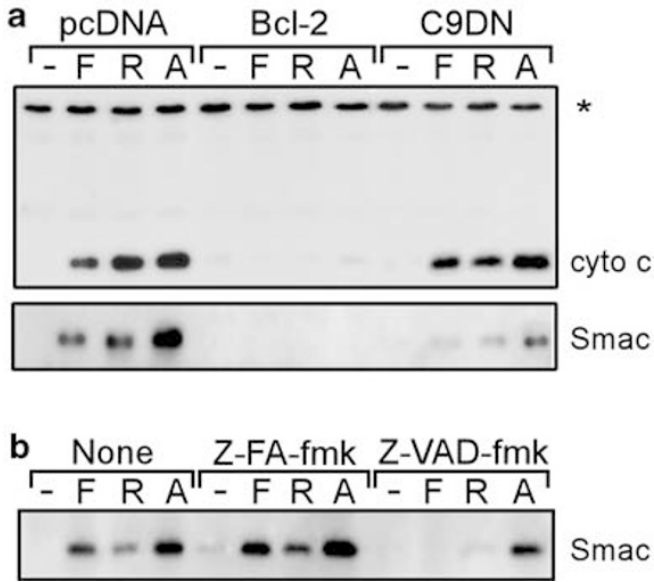

Figure 4 RRM-mediated release of cytochrome $c$ and Smac/Diablo in the presence of caspase inhibitors. (a) Effect of Bcl-2 and C9DN overexpression on the translocation of mitochondrial proteins. Jurkat cells were treated for $3 \mathrm{~h}$ with solvent (-), $167 \mathrm{ng} / \mathrm{ml}$ anti-Fas antibody (F), $1 \mu \mathrm{M}$ MX2870-1 (R), or $4 \mu \mathrm{M}$ MX781 (A). Cytosolic extracts were prepared in ICM buffer and analyzed by immunoblot with antibodies raised against cytochrome $c$ or Smac/Diablo. The asterisk shows a nonspecific band used to normalize protein loading. (b) Jurkat parental cells were preincubated with $100 \mu \mathrm{M}$ Z-FA-fmk, $20 \mu \mathrm{M}$ Z-VAD-fmk, or DMSO (none) for $1 \mathrm{~h}$, and subsequently stimulated with the RRMs or anti-Fas as in (a). Cytosolic extracts were prepared and analyzed by immunoblot with antiSmac/Diablo antibody

bodies was rapidly observed in Jurkat-pcDNA cells treated with the RRMs or anti-Fas, but not in Jurkat-Bcl-2 cells. Distinctive apoptotic bodies were not observed in JurkatC9DN cells. However, a low percentage of these cells were smaller in size and showed morphological alterations reminiscent of irreversible damage, which could lead over time to loss of cell viability (Figure 6). Z-VAD-fmk also prevented the full maturation of apoptotic bodies induced by the RRMs in Jurkat parental cells, but a significant portion of cells were shrunken and showed an altered morphology similar to that observed in C9DN-treated cells. Z-VAD-fmk, however, completely prevented any morphological changes in cells stimulated with anti-Fas, probably due to the effective inhibition of caspase 8 activity upstream of mitochondrial damage (Figure 6).

\section{RRMs can induce cell death in the absence of caspase activity}

We next analyzed the viability of C9DN- and $\mathrm{Bcl}-2$-expressing Jurkat cells after $24 \mathrm{~h}$ of RRM treatment. RRM treatment inhibited the proliferation of Jurkat-Bcl-2 cells, whereas antiFas antibody elicited minimal effects (Figure 7a). Noteworthy, Jurkat-C9DN cells showed reduced cell viability when treated with the different stimuli, which could be due, at least in part, to the low levels of DEVDase activity detected after prolonged periods of incubation (see Figure 2). However, caspaseindependent death could not be ruled out. Indeed, Z-VAD-fmk showed a minor protection against RRM-induced cell death in Jurkat parental cells, while completely preventing cell death induced by anti-Fas, which indicated an effective inhibition of caspase 8 signaling (Figure 7b). The concentration of Z-VADfmk used was sufficient to block the induction of DEVDase-like 


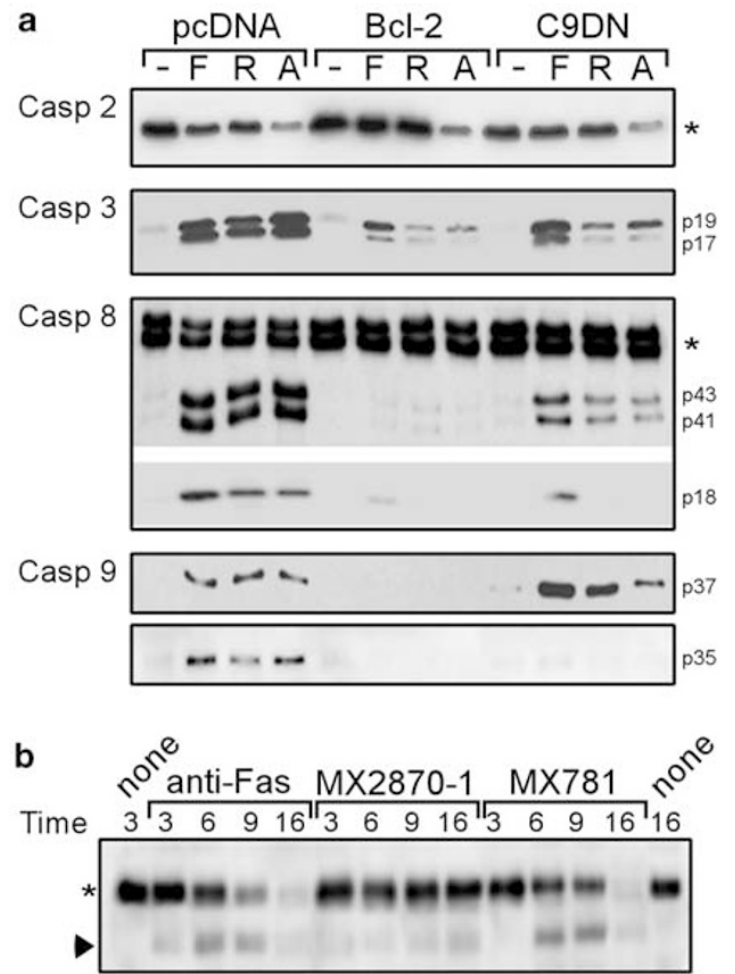

Figure 5 Cleavage of caspases in C9DN- and Bcl-2-expressing cells. (a) Cell extracts obtained in the experiment described in Figure 4a were analyzed for caspase cleavage using antibodies described in Materials and Methods. Cleaved caspase 3 (p19/p17), cleaved caspase 9 (p37 (cleavage at Asp330) and p35 (cleavage at Asp315)), and the proteolytic fragments of caspase 8 (p43/p41 and p18) are shown. Procaspases 2 and 8 are indicated with asterisk. The lower part of the membrane immunoblotted with anticaspase 8 antibody was exposed for a longer time to detect the p18 fragment. (b) Cleavage of procaspase 9. JurkatC9DN-1 cells were stimulated as before, and cell extracts were prepared at the indicated times (in hours). Expression of full-length caspase 9 was analyzed by immunoblot. Full-length (*) and the proteolytic fragments (arrowhead) are shown. All these experiments were performed at least three times with similar results. The results of one representative experiment are shown here

activity after $24 \mathrm{~h}$ of RRM or Fas stimulation. These data demonstrate that continuous exposure to RRMs can induce cell death in the absence of caspase activity.

\section{RRMs induce cell cycle arrest independently of the retinoid receptors}

The results described above suggested that the RRMs could induce cell cycle arrest when the apoptotic process is blocked. In this context, CD437 has been shown to induce growth arrest in $\mathrm{G} 1^{28,59,60}$ or $\mathrm{S}$ phase $\mathrm{s}^{55,61,62}$ in a variety of tumor cell lines as well as in normal mammary epithelial cells. We therefore analyzed the effect of MX2870-1 and MX781 on cell cycle progression in Jurkat-Bcl-2 cells. When we treated cells for $24 \mathrm{~h}$ with low concentrations of the agonist MX2870-1, we observed a substantial inhibition of DNA synthesis and $S$ phase arrest. In contrast, high concentrations $(1 \mu \mathrm{M})$ of MX2870-1 completely blocked DNA synthesis and caused arrest in G1 (Figure 8a). Interestingly, the antagonist MX781 also prevented incorporation of 5-bromo-2'-deoxyuridine
(BrdU), but cells were primarily arrested in G2/M phase with a slight increase in the G1 population (Figure 8a). No DEVDase activity was detected in Jurkat-Bcl-2 cells after $24 \mathrm{~h}$ of RRM treatment, indicating a cell cycle arrest independent of caspase activity (not shown). A similar cell cycle arrest was observed in other cell lines, including A549 nonsmall lung carcinoma cells, HeLa, K-562, and CV-1 cells (data not shown).

We next examined the effect of the RRMs on the expression levels of cell cycle regulatory proteins. Treatment with MX2870-1 provoked a substantial decrease in cyclin A and B1 protein levels in a concentration-dependent manner, whereas cyclin $\mathrm{E}$ remained unchanged (Figure $8 \mathrm{~b}$ ). The antagonist MX781 also caused a significant reduction in the levels of cyclin A, B1 as well as E. These data correlated with the arrest at G2/M phase by the antagonist, and at G1 phase by MX2870-1. We next analyzed the phosphorylation status of $\mathrm{Rb}$, which is an important regulator of the $\mathrm{G} 1$ to $\mathrm{S}$ transition. A nearly complete inhibition of phospho- $\mathrm{Rb}$ was observed in Jurkat-Bcl-2 cells treated with MX781, whereas the agonist MX2870-1 reduced the levels of phospho- $\mathrm{Rb}$ to a lesser degree. Conversely, total $\mathrm{Rb}$ protein levels remained unchanged in MX2870-1-treated cells, although a significant reduction was detected in cells treated with the antagonist (Figure 8b). Protein loading was normalized by immunobloting with a cdk2 antibody.

Finally, we explored the potential role of the retinoid receptors in RRM-mediated cell cycle arrest. The endogenous receptors in Jurkat-Bcl-2 cells were saturated with an excess of all-trans-retinoic acid or one retinoid antagonist, CD2665, neither of which shows antiproliferative activity on their own (not shown). After $24 \mathrm{~h}$ of RRM exposure, we observed that neither RA nor CD2665 elicited any effect on RRM-induced cell cycle arrest (Figure $8 \mathrm{c}$ ), suggesting a retinoid receptorindependent mechanism of action.

\section{Discussion}

Certain synthetic retinoids that are selective for a subset of retinoid receptors have shown enhanced potency against a variety of cancer cell lines and some are effective in animal models with no overt signs of toxicity. ${ }^{33,34}$ These compounds are therefore promising leads for the development of novel retinoid-like anticancer drugs. Two types of RRMs with opposite activities, the RAR $\gamma$-selective agonists, represented here by $M X 2870-1$, and the antagonist, $M X 781$, induce apoptosis in a caspase-mediated, retinoid receptor-independent manner. ${ }^{29,32,36,63}$ Several lines of evidence indicate that RRMs induce apoptosis through the intrinsic pathway. These are: a caspase-independent, JNK-mediated release of cytochrome $c,^{39,48}$ direct targeting of mitochondria; ${ }^{37}$ and this study in which we demonstrate that the rapid induction of DEVDase-like activity and other caspase-mediated apoptotic events by RRMs are severely impaired in cells lacking caspase 9 activity. Moreover, overexpression of $\mathrm{Bcl}-2 / \mathrm{Bcl}-$ $\mathrm{X}_{\mathrm{L}}$, but not cFLIP (our unpublished observations), inhibits RRM-induced apoptosis. In addition, our data support that the agonist MX2870-1 induces apoptosis via caspase 9, while the antagonist MX781 initiates cell death via caspase 2 . 


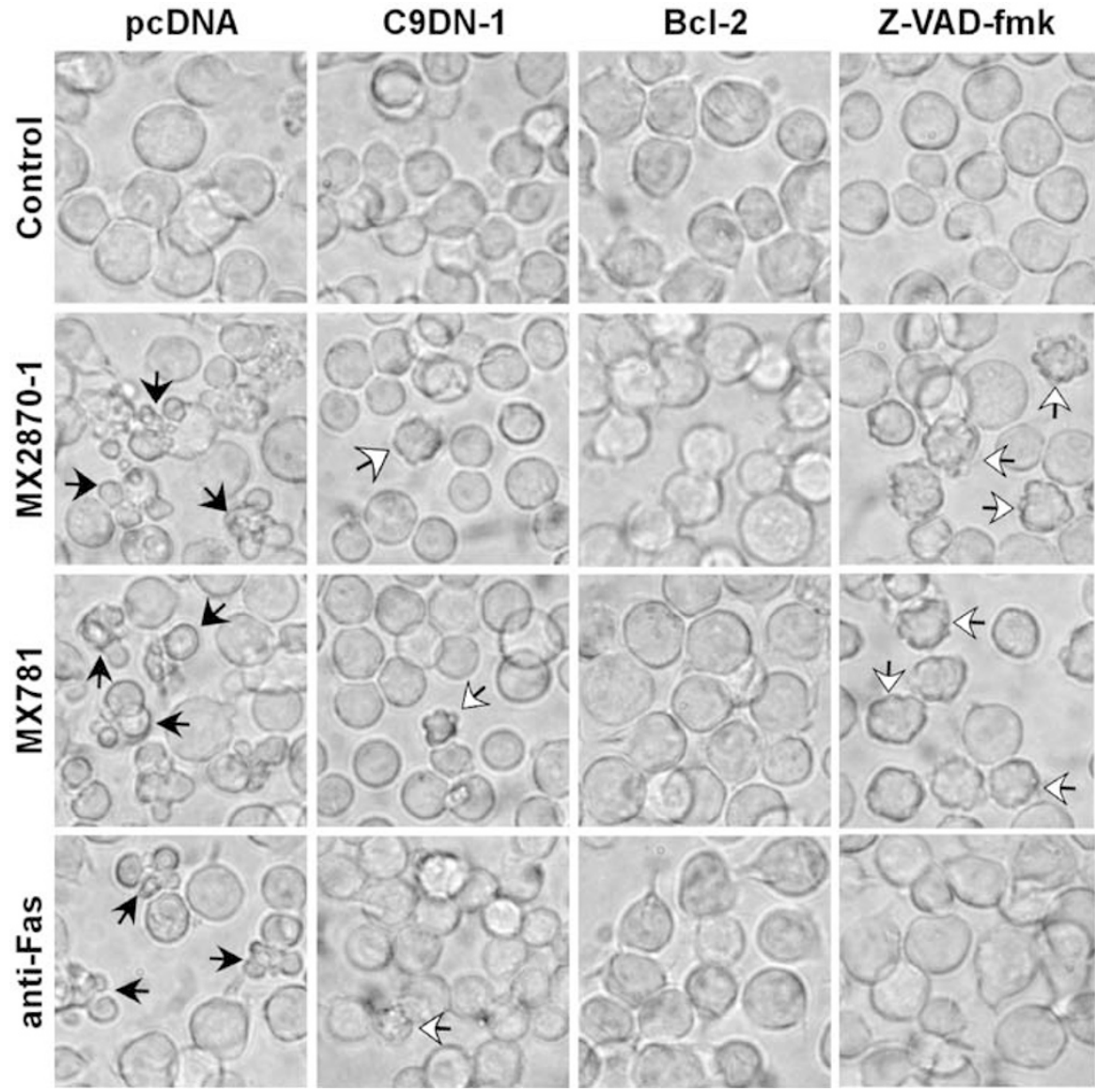

Figure 6 Full maturation of apoptotic bodies requires caspase activity. Jurkat cells stably transfected with C9DN, Bcl-2, or pcDNA vector were treated with solvent (control), $167 \mathrm{ng} / \mathrm{ml}$ anti-Fas antibody, $1 \mu \mathrm{M}$ MX2870-1, or $4 \mu \mathrm{M} \mathrm{MX781}$ and visualized under light microscopy after $3 \mathrm{~h}$ of exposure. Parental cells were preincubated with $20 \mu \mathrm{M}$ Z-VAD-fmk for $1 \mathrm{~h}$ prior to stimulation as before. Black arrows indicate characteristic mature apoptotic bodies. White arrows show shrunken cells with altered morphology. The pictures are representative of three independent experiments, which produced identical results

Overexpression of a catalytically inactive form of caspase 9 significantly inhibits the autoproteolytic maturation of the procaspase. We demonstrate that caspase 9 activity plays a critical role in the effective release of Smac/Diablo from the mitochondria, which has recently been shown to require caspase activity and is inhibited by Z-VAD-fmk (see Figure $4 \mathrm{~b}$ and Adrain et al. ${ }^{58}$ ). In agreement with its functional role during apoptosis, ${ }^{6,7}$ the impaired translocation of Smac observed in cells overexpressing C9DN correlates with diminished induction of DEVDase activity. It is noteworthy that MX2870-1 failed to provoke Smac release in JurkatC9DN cells, while the antagonist MX781 induced a reduced but significant release as compared to control cells. The latter is possibly due to the activation of caspase 2 , which occurs independently of caspase 9 activity in MX781-treated cells and may provoke the translocation of proapoptotic proteins from the mitochondria. ${ }^{15,16,64}$ This assumption is further supported by our observations that Z-VAD-fmk, a poor inhibitor of caspase $2,{ }^{65}$ weakly prevented MX781-mediated release of Smac.

We present evidence that the antagonist MX781 activates caspase 2 in a caspase 9-independent manner, akin to stressinduced apoptosis in E1A-transformed human fibroblasts. ${ }^{17}$ This contrasts with the requirement of caspase 9 activity for the efficient cleavage of procaspase 2 by MX2870-1 and Fas signals. The latter resembles the activation of caspase 2 by effector caspases upon activation of the mitochondrial pathway, ${ }^{13}$ as observed in UV- and TNF-dependent apoptosis. ${ }^{66}$ Despite the activation of caspase 2 by MX781 in cells overexpressing $\mathrm{Bcl}-2$ or C9DN, this is not sufficient to cause the rapid induction of DEVDase activity that is observed in control cells, in which the mitochondria-caspase 9 loop is functional. No substrates for caspase 2 have been identified, with the exception of golgin $\mathrm{p} 160^{67}$ and, therefore, the consequences of caspase 2 activity other than targeting mitochondria ${ }^{15,16,64}$ are not completely understood. The activation of caspase 2 upstream of caspase 9 is perhaps responsible for the degradation of PARP observed in JurkatC9DN cells stimulated with MX781, which occurs in the presence of low levels of DEVDase activity. Similar PARP cleavage is seen in Fas-stimulated cells, probably mediated by caspase 8 signaling. In contrast, much reduced cleavage of PARP is observed in MX2870-1-treated cells, which further suggests an apical role for caspase 9 in the induction of apoptosis by the RRM agonist.

In addition to caspase-mediated cell death, which exhibits typical characteristics of apoptosis, the RRMs can also induce caspase-independent death. This is evident in C9DN-expres- 

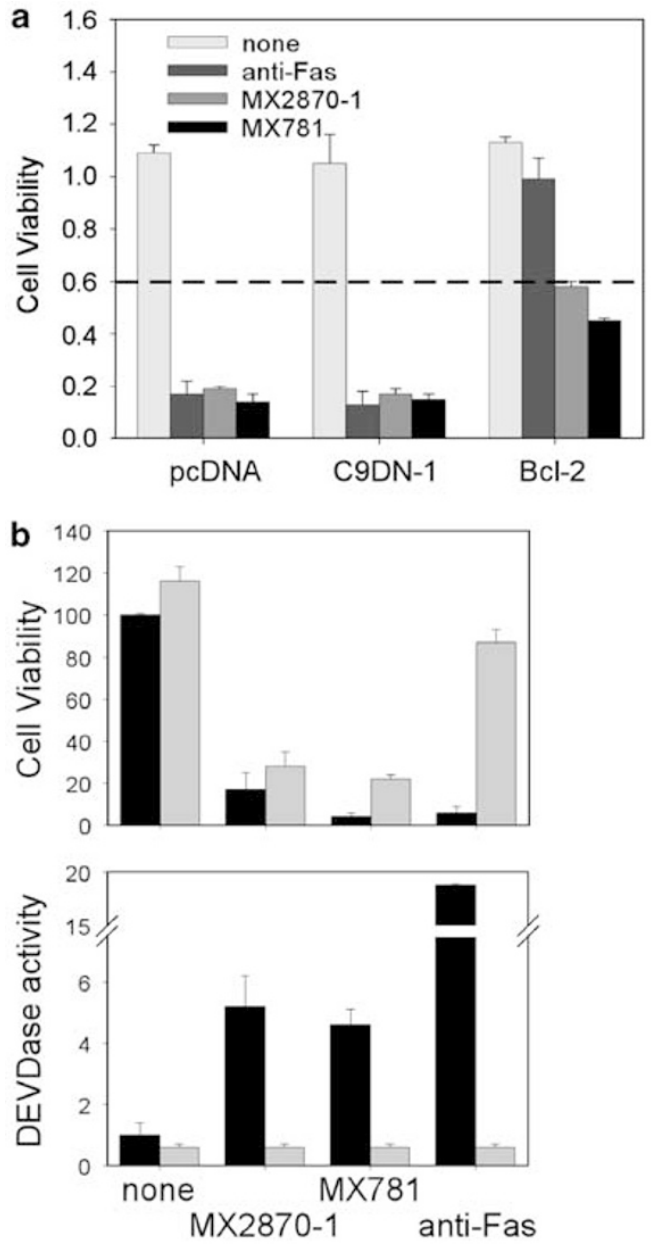

Figure 7 Selective RRMs induce caspase-independent cell death. (a) Bcl-2 inhibits RRM-induced cell death. Cells transfected with pcDNA, C9DN, or Bcl-2 were incubated for $24 \mathrm{~h}$ with solvent (none), $167 \mathrm{ng} / \mathrm{ml}$ anti-Fas antibody, $1 \mu \mathrm{M}$ MX2870-1, or $4 \mu \mathrm{M} M X 781$, and then cell viability was determined by trypan blue exclusion. The concentration of viable cells (in $10^{6}$ cells per $\mathrm{ml}$ ) is indicated. The dotted line shows the cell density at the beginning of the experiment. The data represent the average \pm S.D. of three independent experiments. (b) RRMs, but not anti-Fas antibody, induce cell death independently of caspase activity. Jurkat parental cells were treated for $24 \mathrm{~h}$ as above in the absence (black column) or in the presence (gray column) of $20 \mu \mathrm{M}$ Z-VAD-fmk. Cell viability (top) was determined by trypan blue exclusion. The percentage of viable cells relative to nonstimulated cells is indicated. An aliquot of the cells was used to prepare cell extracts, which were assayed for DEVDase activity (bottom). The values shown are the average \pm S.D. of two independent experiments

sing cells and in parental cells stimulated in the presence of Z-VAD-fmk. The release of proapoptotic factors from the mitochondria that occurs in the absence of caspase 3/7-like activity probably contributes to the loss of cell viability upon RRM stimulation. In addition to cytochrome $c$ and Smac, other proteins including serine proteases and endonucleases are released from the mitochondria, which can cause cell death independently of caspase activity. Both events, mitochondrial damage and loss of cell viability, are efficiently inhibited by $\mathrm{Bcl}-2$ overexpression, which prevents the release of cytochrome $c$ and Smac, and perhaps other proapoptotic factors. While the agonist MX2870-1 does not require caspase activity to cause mitochondrial damage, caspase 2 may be involved in MX781 function. Whether caspase 2 is

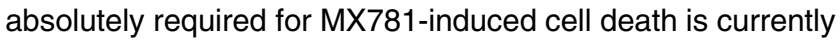
under investigation.

Selective RRMs cause cell cycle arrest when the apoptotic program is blocked (in Bcl-2-overexpressing cells). We show here that, similar to CD437, the analog MX2870-1 induces cell cycle arrest in $\mathrm{G} 1$ or $\mathrm{S}$ phase in a concentration-dependent manner. Thus, the differences reported in the literature with CD437 could reflect differences on the RRM concentration and not differences on cell types. MX2870-1-induced G1 arrest correlates with decreased levels of cyclin A and B1, which mirrors a reduction in the phosphorylation levels of $\mathrm{Rb}^{68}$ Interestingly, the antagonist MX781 induces arrest primarily in G2/M phase concurrent with diminished levels of cyclin A, B1, and $E$. The inhibition of Rb phosphorylation by MX781 is accompanied by diminished levels of total $R b$, which could be due to caspase-mediated degradation. ${ }^{69-71}$ Although no DEVDase activity is detected after $24 \mathrm{~h}$ of treatment in Jurkat-Bcl-2 cells, we cannot rule out a potential role for caspase 2 , which is activated upstream of mitochondria and independently of Bcl-2, in MX781-mediated $\mathrm{Rb}$ degradation and cell cycle arrest. In addition to $\mathrm{Rb}$ degradation, we cannot exclude a direct effect of $M X 781$ on $R b$ phosphorylation via inhibition of CDK activity or activation of an $\mathrm{Rb}$ phosphatase. Whether the RRMs directly induce cyclin degradation and/or $\mathrm{Rb}$ dephosphorylation followed by cell cycle arrest or vice versa needs to be elucidated.

In summary, we have shown that caspase 9 activity is required for the effective release of Smac and the rapid induction of apoptosis by the agonist RRM MX2870-1. However, the induction of apoptosis by the antagonist MX781, which presumably occurs via caspase 2 , experiences a delay in the absence of caspase 9 activity. Both RRMs can also induce caspase-independent cell death and cell cycle arrest, which could be relevant for their antiproliferative activity against tumors with reduced apoptosis rates.

\section{Materials and Methods}

\section{Cells and reagents}

Jurkat cells were cultured in RPMI containing $10 \%$ of heat-inactivated fetal bovine serum, nonessential amino acids, $2 \mathrm{mM}$ glutamine, $100 \mathrm{U} / \mathrm{ml}$ penicillin, and $100 \mu \mathrm{g} / \mathrm{ml}$ streptomycin. Cell viability was determined by trypan blue exclusion, after incubating cells in $0.2 \%(\mathrm{w} / \mathrm{v})$ trypan blue (Sigma) and counting white cells using a hemocytometer. The expression vector for a Flag-tagged catalytically inactive form of caspase 9 (C9DN) with a single point mutation (C285A) was obtained from Dr. C. Vincenz (University of Michigan, Ann Arbor). ${ }^{49}$ pSSFV-Bcl-2 expression vector was a gift of Dr. S. Korsmeyer (Dana Farber Cancer Institute, Boston) and pSSFV-Bcl- $X_{L}$ was obtained from Dr. C. Thompson (Abramson Family Cancer Research Institute, Philadelphia). RRMs were obtained from Maxia Pharmaceuticals and Galderma R\&D, and $10 \mathrm{mM}$ stock solutions were prepared in DMSO. RRM treatment was performed in medium containing $0.5 \%$ serum. Caspase inhibitors (Enzyme Systems Products) were added $1 \mathrm{~h}$ prior to stimulation. During long-term experiments, fresh inhibitor was added to the culture medium every 8-12 h. Anti-Fas antibody (clone IPO-4) was purchased from Kamiya Biomedical. 

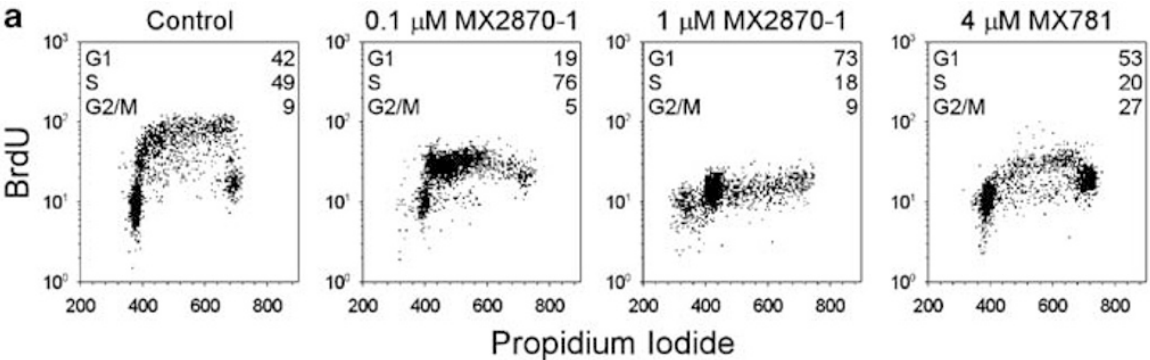

b
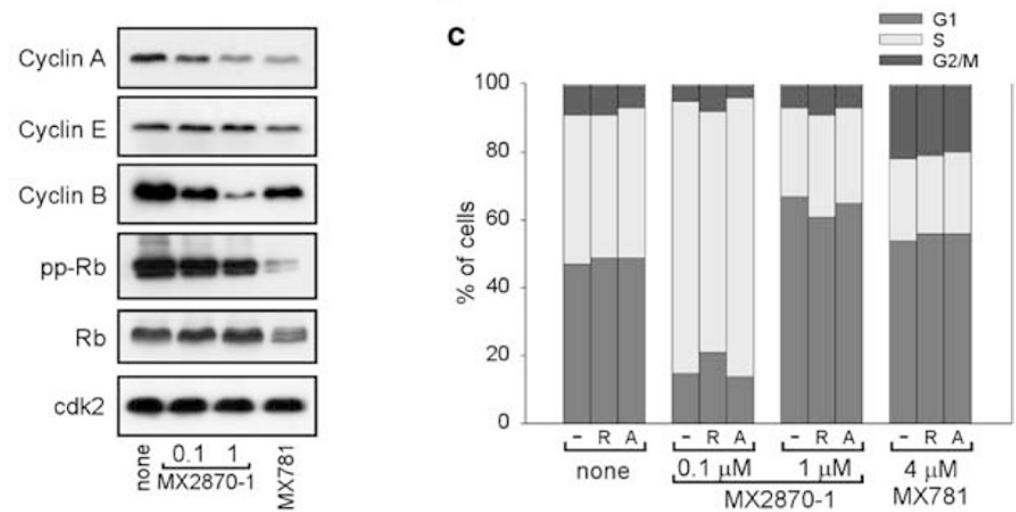

Figure 8 Effect of selective RRMs on cell cycle. (a) RRMs induce cell cycle arrest. Jurkat-Bcl-2 cells were treated in the presence of the indicated RRMs for $24 \mathrm{~h}$, when DNA replication (anti-BrdU labeling) and the amount of DNA (PI staining) were analyzed by flow cytometry. The percentage of cells in each phase of the cell cycle is indicated. (b) Effect of RRM treatment on cell cycle-related protein levels. Cells treated as before were lysed and analyzed by Western blot for the expression levels of the indicated proteins. Levels of cdk2 were used as loading control. (c) Cell cycle arrest is independent of the retinoid receptors. Jurkat-Bcl-2 cells were incubated with the indicated RRMs in the absence $(-)$ or in the presence of $12 \mu \mathrm{M}$ retinoic acid $(\mathrm{R})$ or the retinoid antagonist CD2665 (A). After $24 \mathrm{~h}$ of incubation, cells were double stained with anti-BrdU-FITC and PI followed by flow cytometry. The percentage of cells in each phase of the cell cycle is indicated

\section{Transfection of Jurkat T cells}

Exponentially growing Jurkat cells were electroporated with $7 \mu \mathrm{g}$ of plasmid with a $215 \mathrm{~V}, 55 \mathrm{~ms}$ pulse using an ECM 830 Electro Square Porator (BTX). To isolate stable transfected cells, $2 \mathrm{mg} / \mathrm{ml}$ neomycin (Calbiochem) was added 2 days after electroporation and cells were selected for 15 days in the presence of the drug. Individual clones were isolated by limiting dilution and maintained in medium containing $0.5 \mathrm{mg} /$ $\mathrm{ml}$ neomycin. The expression of the proteins of interest in the isolated clones was assessed by immunoblot using the following antibodies: FlagC9DN (M2, Sigma), Bcl-2, and Bcl- $\mathrm{X}_{\mathrm{L}}$ (Pharmingen).

\section{Assessment of apoptosis}

DEVDase activity was measured in cell extracts prepared in CE buffer (25 mM PIPES pH 7, $25 \mathrm{mM} \mathrm{KCl,} 5 \mathrm{mM}$ EGTA, $1 \mathrm{mM}$ DTT, $10 \mu \mathrm{M}$ cytochalasin $\mathrm{B}, 0.5 \% \mathrm{NP}-40$, and a mixture of protease inhibitors consisting of $1 \mathrm{mM} \mathrm{PMSF}, 1 \mu \mathrm{g} / \mathrm{ml}$ leupeptine, and $1 \mu \mathrm{g} / \mathrm{ml}$ aprotinin). In total, $10 \mu \mathrm{g}$ of protein was diluted in $100 \mu \mathrm{l}$ of caspase buffer $(50 \mathrm{mM}$ HEPES pH 7.4, $100 \mathrm{mM} \mathrm{NaCl}, 1 \mathrm{mM}$ EDTA, $5 \mathrm{mM}$ DTT, 0.1\% CHAPS, and $10 \%$ sucrose) containing $100 \mu \mathrm{M}$ of Ac-DEVD-AFC (Enzyme System Products). Reactions were incubated at $37^{\circ} \mathrm{C}$ for $30 \mathrm{~min}$, and the release of free 7-amino-trifluoromethyl coumarin (AFC) was measured every 3 min at $510 \mathrm{~nm}$ emission upon excitation at $390 \mathrm{~nm}$, using a Victor2 microplate reader (Perkin-Elmer).

DNA fragmentation was measured with $2 \mu \mathrm{g}$ of protein extract prepared in CE buffer using a Cell Death Detection ELISA (Roche), following the manufacturer's instructions.
Nuclear morphology was examined by Hoescht staining. Cells were collected after treatment, washed once with phosphate buffer solution (PBS) and cytospun onto glass slides. Cells were fixed for $15 \mathrm{~min}$ at room temperature in $3.7 \%$ paraformaldehyde solution in PBS. Cells were washed twice with PBS and subsequently stained with $1 \mu \mathrm{g} / \mathrm{ml}$ Hoescht 33258 (in PBS) for $30 \mathrm{~min}$ in the dark. Finally, cells were washed twice with PBS to remove the excess of dye and images were captured using a DeltaVision Deconvolution Restoration system mounted on an Olympus IX70 inverted microscope.

\section{Immunoblot analysis of caspase activation and release of cytochrome $c$ and Smac}

Jurkat cells $\left(2.5 \times 10^{6}\right)$ were treated and lysed in $50 \mu$ l of ICM buffer $\left(120 \mathrm{mM} \mathrm{KCl}, 10 \mathrm{mM} \mathrm{NaCl}, 1 \mathrm{mM} \mathrm{KH_{2 }} \mathrm{PO}_{4}, 20 \mathrm{mM}\right.$ Hepes-Tris $\mathrm{pH}$ 7.1, $2 \mathrm{mM}$ succinate, $100 \mu \mathrm{g} / \mathrm{ml}$ digitonin, and protease inhibitors). In total, 20 $50 \mu \mathrm{g}$ of protein extracts were analyzed in a $17.5 \%$ SDS-polyacrylamide gel and transferred to Immobilon-P membrane. Cytochrome $c$ and Smac were analyzed with antibodies obtained from Dr. X. Wang (University of Texas Medical Center). Caspase processing was analyzed with antibodies that recognize cleaved caspases 3 (Asp175) and 9 (Asp315 and Asp330) (from Cell Signaling), and with antibodies recognizing the proenzyme and proteolytic fragments of caspases 2 (Santa Cruz), 8 (R\&D), or 9 (Stressgen). Protein extracts prepared in CE, ICM, or RIPA (50 mM Tris

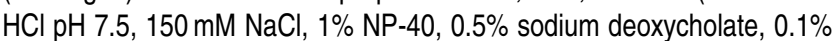
SDS, and protease inhibitors) buffer were used for the immunodetection of caspases. Cleavage of PARP was examined using whole-cell extracts 
prepared in RIPA buffer and anti-PARP monoclonal antibody (C2-10 PharMingen). Immunodetection was performed exactly as described. ${ }^{39}$

\section{Incorporation of BrdU and cell cycle analysis}

Jurkat-Bcl-2 cells were treated for $24 \mathrm{~h}$ with the indicated RRMs, and $10 \mu \mathrm{M} \mathrm{BrdU}$ was added during the last $30 \mathrm{~min}$ of incubation. Cells were collected, washed with PBS and fixed in $70 \%$ ethanol for at least $16 \mathrm{~h}$ at $4{ }^{\circ} \mathrm{C}$. An aliquot of cells was counted, and the same number of cells in each sample was labeled with a FITC-conjugated anti-BrdU antibody (Caltag Laboratories) following the manufacturer's instructions. Subsequently, cells were also stained with $50 \mu \mathrm{g} / \mathrm{ml}$ propidium iodide (PI) in the presence of $100 \mathrm{U} / \mathrm{ml}$ RNase, and analyzed by flow cytometry (FACS Calibur) Singlets were identified in an FL2-area-versus-width dot plot. For the examination of cyclins and $\mathrm{Rb}$ protein levels, whole-cell extracts were prepared in lysis buffer $(50 \mathrm{mM}$ Hepes, $\mathrm{pH} 7.4,100 \mathrm{mM} \mathrm{NaCl}, 1 \mathrm{mM}$ EGTA, $1 \mathrm{mM} \mathrm{MgCl} 2,1 \%$ (v/v) Triton X-100, $20 \mathrm{mM} \mathrm{NaF}, 20 \mathrm{mM} \mathrm{Na}-$ pyrophosphate, $1 \mathrm{mM}$ sodium vanadate, and protease inhibitor mixture). Protein extract $(25 \mu \mathrm{g})$ was separated by SDS-PAGE and immunoblotted with antibodies against cyclins $A, B 1$, and $E$ (Santa Cruz Biotechnology), phospho-(Ser 795)-Rb (Cell Signalling), Rb, and cdk2 (Santa Cruz).

\section{Acknowledgements}

This work was supported by NIH Grant CA75033 to FJP. We thank Renata Hasim for excellent technical support, Brian Smith for capturing the images shown in Figure 1, and Marion Sauter for secretarial assistance. We are especially grateful to S. Korsmeyer, C. Thompson, C. Vincenz, and X. Wang for reagents, M. Pfahl, Maxia Pharmaceuticals, and Galderma R\&D for the synthetic RRMs, and A. Fotedar for helpful discussions.

\section{References}

1. Nicholson DW (1999) Caspase structure, proteolytic substrates, and function during apoptotic cell death. Cell Death Differ. 6: 1028-1042

2. Stennicke HR and Salvesen GS (2000) Caspases - controlling intracellular signals by protease zymogen activation. Biochim. Biophys. Acta 1477: 299306

3. Wang $X$ (2001) The expanding role of mitochondria in apoptosis. Genes Dev. 15: 2922-2933

4. Suzuki Y, Imai Y, Nakayama H, Takahashi K, Takio K and Takahashi R (2001) A serine protease, $\mathrm{HtrA} 2$, is released from the mitochondria and interacts with XIAP, inducing cell death. Mol. Cell. 8: 613-621

5. Susin SA, Lorenzo HK, Zamzami N, Marzo I, Snow BE, Brothers GM, Mangion J, Jacotot E, Costantini P, Loeffler M, Larochette N, Goodlett DR, Aebersold R, Siderovski DP, Penninger JM and Kroemer G (1999) Molecular characterization of mitochondrial apoptosis-inducing factor. Nature 397: 441446

6. Du C, Fang M, Li Y, Li L and Wang X (2000) Smac, a mitochondrial protein that promotes cytochrome $c$-dependent caspase activation by eliminating IAP inhibition. Cell 102: 33-42

7. Verhagen AM, Ekert PG, Pakusch M, Silke J, Connolly LM, Reid GE, Moritz RL Simpson RJ and Vaux DL (2000) Identification of DIABLO, a mammalian protein that promotes apoptosis by binding to and antagonizing IAP proteins. Cell 102: 43-53

8. Li LY, Luo X and Wang X (2001) Endonuclease $G$ is an apoptotic DNase when released from mitochondria. Nature 412: 95-99

9. LI P, Nijhawan D, Budihardjo I, Srinivasula SM, Ahmad M, Alnemri ES and Wang X (1997) Cytochrome $c$ and dATP-dependent formation of Apaf-1/ caspase-9 complex initiates an apoptotic protease cascade. Cell 91: 479-489
10. Zou H, Henzel WJ, Liu X, Lutschg A and Wang X (1997) Apaf-1, a human protein homologous to $C$. elegans CED-4, participates in cytochrome $c$ dependent activation of caspase-3. Cell 90: 405-413

11. Srinivasula SM, Ahmad M, Fernandes-Alnemri T and Alnemri ES (1998) Autoactivation of procaspase- 9 by Apaf-1-mediated oligomerization. Mol. Cell. 1: $949-957$

12. Rodriguez $\mathrm{J}$ and Lazebnik $Y$ (1999) Caspase-9 and APAF-1 form an active holoenzyme. Genes Dev. 13: 3179-3184

13. Slee EA, Harte MT, Kluck RM, Wolf BB, Casiano CA, Newmeyer DD, Wang HG, Reed JC, Nicholson DW, Alnemri ES, Green DR and Martin SJ (1999) Ordering the cytochrome $c$-initiated caspase cascade: hierarchical activation of caspases-2, -3, -6, -7, -8, and -10 in a caspase-9-dependent manner. J. Cell Biol. 144: 281-292

14. Zou H, Li Y, Liu X and Wang X (1999) An APAF-1.cytochrome c multimeric complex is a functional apoptosome that activates procaspase-9. J. Biol. Chem. 274: 11549-11556

15. Robertson JD, Enoksson M, Suomela M, Zhivotovsky B and Orrenius S (2002) Caspase-2 acts upstream of mitochondria to promote cytochrome $c$ release during etoposide-induced apoptosis. J. Biol. Chem. 277: 29803-29809

16. Guo Y, Srinivasula SM, Druilhe A, Fernandes-Alnemri T and Alnemri ES (2002) Caspase-2 induces apoptosis by releasing proapoptotic proteins from mitochondria. J. Biol. Chem. 277: 13430-13437

17. Lassus $P$, Opitz-Araya $X$ and Lazebnik $Y$ (2002) Requirement for caspase-2 in stress-induced apoptosis before mitochondrial permeabilization. Science 297: 1352-1354

18. Medema JP, Scaffidi C, Kischkel FC, Shevchenko A, Mann M, Krammer PH and Peter ME (1997) FLICE is activated by association with the CD95 deathinducing signaling complex (DISC). EMBO J. 16: 2794-2804

19. Bodmer JL, Holler N, Reynard S, Vinciguerra P, Schneider P, Juo P, Blenis J and Tschopp J (2000) TRAIL receptor-2 signals apoptosis through FADD and caspase-8. Nat. Cell Biol. 2: 241-243

20. Walczak H and Sprick MR (2001) Biochemistry and function of the DISC. Trends Biochem. Sci. 26: 452-453

21. Fernandes-Alnemri T, Armstrong RC, Krebs J, Srinivasula SM, Wang L, Bullrich F, Fritz LC, Trapani JA, Tomaselli KJ, Litwack G and Alnemri ES (1996) In vitro activation of CPP32 and Mch3 by Mch4, a novel human apoptotic cysteine protease containing two FADD-like domains. Proc. Natl. Acad. Sci. USA 93: 7464-7469

22. Muzio M, Salvesen GS and Dixit VM (1997) FLICE induced apoptosis in a cell-free system. Cleavage of caspase zymogens. J. Biol. Chem. 272: 2952-2956

23. Stennicke HR, Jurgensmeier JM, Shin H, Deveraux Q, Wolf BB, Yang X, Zhou Q, Ellerby HM, Ellerby LM, Bredesen D, Green DR, Reed JC, Froelich CJ and Salvesen GS (1998) Pro-caspase-3 is a major physiologic target of caspase-8. J. Biol. Chem. 273: 27084-27090

24. Luo X, Budihardjo I, Zou H, Slaughter C and Wang X (1998) Bid, a Bcl2 interacting protein, mediates cytochrome $c$ release from mitochondria in response to activation of cell surface death receptors. Cell 94: 481-490

25. Li H, Zhu H, Xu C-J and Yuan J (1998) Cleavage of BID by caspase 8 mediates the mitochondrial damage in the Fas pathway of apoptosis. Cell 94 : 491-501

26. Wesselborg S, Engels IH, Rossmann E, Los M and Schulze-Osthoff K (1999) Anticancer drugs induce caspase-8/FLICE activation and apoptosis in the absence of CD95 receptor/ligand interaction. Blood 93: 3053-3063

27. Ferreira CG, Span SW, Peters GJ, Kruyt FA and Giaccone G (2000) Chemotherapy triggers apoptosis in a caspase-8-dependent and mitochondriacontrolled manner in the non-small cell lung cancer cell line $\mathrm{NCl}-\mathrm{H} 460$. Cancer Res. 60: 7133-7141

28. Shao Z-M, Dawson MI, Li XS, Rishi AK, Sheikh MS, Han Q-X, Ordonez V, Shroot B and Fontana JA (1995) p53 independent G0/G1 arrest and apoptosis induced by a novel retinoid in human breast cancer cells. Oncogene 11: 493504

29. Piedrafita FJ and Pfahl M (1997) Retinoid-induced apoptosis and Sp1 cleavage occur independently of transcription and require caspase activation. Mol. Cell. Biol. 17: 6348-6358

30. Sun SY, Yue P, Shroot B, Hong WK and Lotan R (1997) Induction of apoptosis in human non-small cell lung carcinoma cells by the novel synthetic retinoid CD437. J. Cell Physiol. 173: 279-284 
31. Adachi H, Preston G, Harvat B, Dawson Ml and Jetten AM (1998) Inhibition of cell proliferation and induction of apoptosis by the retinoid AHPN in human lung carcinoma cells. Am. J. Resp. Cell Mol. Biol. 18: 323-333

32. Bayon Y, Ortiz MA, Lopez-Hernandez FJ, Gao F, Karin M, Pfahl M and Piedrafita FJ (2003) Inhibition of IкB kinase by a new class of retinoid-related anticancer agents that induce apoptosis. Moll. Cell. Biol. 23: 1061-1074

33. Lu XP, Fanjul AN, Picard N, Pfahl M, Rungta D, Nared-Hood K, Carter B, Piedrafita FJ, Tang S, Fabbrizio E and Pfahl M (1997) Novel retinoid-related molecules as apoptosis inducers and effective inhibitors of human lung cancer cells in vivo. Nat. Med. 3: 686-690

34. Fanjul AN, Piedrafita FJ, Al-Shamma H and Pfahl M (1998) Apoptosis induction and potent antiestrogen receptor-negative breast cancer activity in vivo by a retinoid antagonist. Cancer Res. 58: 4607-4610

35. Ortiz MA, Bayon Y, Lopez-Hernandez FJ and Piedrafita FJ (2002) Retinoids in combination therapies for the treatment of cancer: mechanisms and perspectives. Drug Resist. Update 5: 162-175

36. Hsu CA, Rishi AK, Su-Li X, Gerald TM, Dawson MI, Schiffer C, Reichert U, Shroot B, Poirer GC and Fontana JA (1997) Retinoid induced apoptosis in leukemia cells through a retinoic acid nuclear receptor-independent pathway. Blood 89: 4470-4479

37. Marchetti $P$, Zamzami N, Joseph B, Schraen-Maschke S, Mereau-Richard C, Costantini P, Metivier D, Susin SA, Kroemer G and Formstecher P (1999) The novel retinoid 6-2-naphtalene carboxylic acid can trigger apoptosis through a mitochondrial pathway independent of the nucleus. Cancer Res. 59: 62576266

38. Li H, Kolluri SK, Gu J, Dawson MI, Cao X, Hobbs PD, Lin B, Chen GQ, Lu J, Lin F, Xie Z, Fontana JA, Reed JC and Zhang X (2000) Cytochrome $c$ release and apoptosis induced by mitochondrial targeting of nuclear orphan receptor TR3. Science 289: 1159-1164

39. Ortiz MA, Lopez-Hernandez FJ, Bayon Y, Pfahl M and Piedrafita FJ (2001) Retinoid-related molecules induce cytochrome $c$ release and apoptosis through activation of c-Jun $\mathrm{NH}(2)$-terminal kinase/p38 mitogen-activated protein kinases. Cancer Res. 61: 8504-8512

40. Tournier C, Hess P, Yang DD, Xu J, Turner TK, Nimnual A, Bar-Sagi D, Jones SN, Flavell RA and Davis RJ (2000) Requirement of JNK for stress-induced activation of the cytochrome $c$-mediated death pathway. Science 288: 870-874

41. Srivastava RK, Mi QS, Hardwick JM and Longo DL (1999) Deletion of the loop region of Bcl-2 completely blocks paclitaxel-induced apoptosis. Proc. Natl. Acad. Sci. USA 96: 3775-3780

42. Yamamoto K, Ichijo $\mathrm{H}$ and Korsmeyer S (1999) Bcl-2 is phosphorylated and inactivated by an ASK1/Jun $\mathrm{N}$-terminal protein kinase pathway normally activated at G2/M. Moll. Cell. Biol. 19: 8469-8478

43. Kharbanda S, Saxena S, Yoshida K, Pandey P, Kaneki M, Wang Q, Cheng K, Chen YN, Campbell A, Sudha T, Yuan ZM, Narula J, Weichselbaum R, Nalin C and Kufe D (2000) Translocation of SAPK/JNK to mitochondria and interaction with bcl-x(L) in response to DNA damage. J. Biol. Chem. 275: 322-327

44. Ito T, Deng X, Carr B and May WS (1997) Bcl-2 phosphorylation required for anti-apoptosis function. J. Biol. Chem. 272: 11671-11673

45. Fang G, Chang BS, Kim CN, Perkins C, Thompson CB and Bhalla KN (1998) 'Loop' domain is necessary for taxol-induced mobility shift and phosphorylation of $\mathrm{Bcl}-2$ as well as for inhibiting taxol-induced cytosolic accumulation of cytochrome $c$ and apoptosis. Cancer Res. 58: 3202-3208

46. Donovan N, Becker EB, Konishi Y and Bonni A (2002) JNK phosphorylation and activation of BAD couples the stress-activated signaling pathway to the cell death machinery. J. Biol. Chem. 277: 40944-40949

47. Lei K and Davis RJ (2003) JNK phosphorylation of Bim-related members of the Bcl2 family induces Bax-dependent apoptosis. Proc. Natl. Acad. Sci. USA 100: 2432-2437

48. Lopez-Hernandez FJ, Ortiz MA, Bayon Y and Piedrafita FJ (2003) Z-FA-fmk inhibits effector caspases but not initiator caspases 8 and 10, and demonstrates that novel anticancer retinoid-related molecules induce apoptosis via the intrinsic pathway. Mol. Cancer Ther. 2: 255-263

49. Duan H, Orth K, Chinnaiyan AM, Poirier GG, Froelich CJ, He WW and Dixit VM (1996) ICE-LAP6, a novel member of the ICE/Ced-3 gene family, is activated by the cytotoxic T cell protease granzyme B. J. Biol. Chem. 271: 16720-16724

50. Pan G, O'Rourke K and Dixit VM (1998) Caspase-9, Bcl-XL, and Apaf-1 form a ternary complex. J. Biol. Chem. 273: 5841-5845
51. Fearnhead HO, Rodriguez J, Govek EE, Guo W, Kobayashi R, Hannon G and Lazebnik YA (1998) Oncogene-dependent apoptosis is mediated by caspase9. Proc. Natl. Acad. Sci. USA 95: 13664-13669

52. Ryan CA, Stennicke HR, Nava VE, Burch JB, Hardwick JM and Salvesen GS (2002) Inhibitor specificity of recombinant and endogenous caspase-9. Biochem. J. 366: 595-601

53. Peter ME and Krammer PH (1998) Mechanisms of CD95 (APO-1/Fas)mediated apoptosis. Curr. Opin. Immunol. 10: 545-551

54. Vu CC, Bortner CD and Cidlowski JA (2001) Differential involvement of initiator caspases in apoptotic volume decrease and potassium efflux during Fas- and UV-induced cell death. J. Biol. Chem. 276: 37602-37611

55. Adachi H, Adams A, Hughes FM, Zhang J, Cidlowski JA and Jetten AM (1998) Induction of apoptosis by the novel retinoid AHPN in human T-cell lymphoma cells involves caspase-dependent and independent pathways. Cell Death Differ. 5: 973-983

56. Armstrong RC, Aja T, Xiang J, Gaur S, Krebs JF, Hoang K, Bai X, Korsmeyer SJ, Karanewsky DS, Fritz LC and Tomaselli KJ (1996) Fas-induced activation of the cell death-related protease CPP32 is inhibited by Bcl-2 and by ICE family protease inhibitors. J. Biol. Chem. 271: 16850-16855

57. Boise LH and Thompson CB (1997) Bcl-x(L) can inhibit apoptosis in cells that have undergone Fas-induced protease activation. Proc. Natl. Acad. Sci. USA 94: 3759-3764

58. Adrain C, Creagh EM and Martin SJ (2001) Apoptosis-associated release of Smac/DIABLO from mitochondria requires active caspases and is blocked by Bcl-2. EMBO J. 20: 6627-6636

59. Li Y, Lin B, Agadir A, Liu R, Dawson MI, Reed JC, Fontana JA, Bost F, Hobbs PD, Zheng Y, Chen GQ, Shroot B, Mercola D and Zhang X (1998) Molecular determinants of AHPN (CD437)-induced growth arrest and apoptosis in human lung cancer cell lines. Moll. Cell. Biol. 18: 4719-4731

60. Sun SY, Yue P, Wu GS, El Deiry WS, Shroot B, Hong WK and Lotan R (1999) Implication of p53 in growth arrest and apoptosis induced by the synthetic retinoid CD437 in human lung cancer cells. Cancer Res. 59: 2829-2833

61. Hsu SL, Yin SC, Liu MC, Reichert U and Ho WL (1999) Involvement of cyclindependent kinase activities in CD437-induced apoptosis. Exp. Cell Res. 252: 332-341

62. Zhang $Y$, Rishi AK, Dawson Ml, Tschang R, Farhana L, Boyanapalli M, Reichert U, Shroot B, Van Buren EC and Fontana JA (2000) S-phase arrest and apoptosis induced in normal mammary epithelial cells by a novel retinoid. Cancer Res. 60: 2025-2032

63. Mologni L, Ponzanelli I, Bresciani F, Sardiello G, Bergamaschi D, Gianni M, Reichert U, Rambaldi A, Terao M and Garattini E (1999) The novel synthetic retinoid 6-2-naphthalene carboxylic acid (CD437) causes apoptosis in acute promyelocytic leukemia cells through rapid activation of caspases. Blood 93: 1045-1061

64. Paroni G, Henderson C, Schneider C and Brancolini C (2002) Caspase-2 can trigger cytochrome $c$ release and apoptosis from the nucleus. J. Biol. Chem. 277: 15147-15161

65. Garcia-Calvo M, Peterson EP, Leiting B, Ruel R, Nicholson DW and Thornberry NA (1998) Inhibition of human caspases by peptide-based and macromolecular inhibitors. J. Biol. Chem. 273: 32608-32613

66. Paroni G, Henderson C, Schneider C and Brancolini C (2001) Caspase-2induced apoptosis is dependent on caspase-9, but its processing during UV- or tumor necrosis factor-dependent cell death requires caspase-3. J. Biol. Chem. 276: 21907-21915

67. Mancini M, Machamer CE, Roy S, Nicholson DW, Thornberry NA, CasciolaRosen LA and Rosen A (2000) Caspase-2 is localized at the Golgi complex and cleaves golgin-160 during apoptosis. J. Cell Biol. 149: 603-612

68. Sherr CJ (1996) Cancer cell cycles. Science 274: 1672-1677

69. An B and Dou QP (1996) Cleavage of retinoblastoma protein during apoptosis: an interleukin 1 beta-converting enzyme-like protease as candidate. Cancer Res. 56: 438-442

70. Dou QP, An B, Antoku K and Johnson DE (1997) Fas stimulation induces RB dephosphorylation and proteolysis that is blocked by inhibitors of the ICE protease family. J. Cell Biochem. 64: 586-594

71. Chau BN, Borges HL, Chen TT, Masselli A, Hunton IC and Wang JY (2002) Signal-dependent protection from apoptosis in mice expressing caspaseresistant $\mathrm{Rb}$. Nat. Cell Biol. 4: 757-765 